www.cjes.eu

Birlesik Dunya Arastrrma Cypriot Journal of Educational

\title{
Organizational technics for developing the leadership potential of students in self-government
}

Zhumasheva Tolkyn ${ }^{\mathrm{a}}$, PhD student, Department of pre-school education and social pedagogy, Abai Kazakh National Pedagogical University, Dostyk ave.13, 050010, Almaty, Kazakhstan.

Alimbekova Anar ${ }^{\mathrm{b}}$, PhD Doctor, Department of Preschool Education and Social Pedagogy, Abai Kazakh National Pedagogical University, Dostyk ave.13, 050010, Almaty, Kazakhstan. https://orcid.org/0000-0001-5154$\underline{9560}$

Akhmaral Khairzhanova Khatifovna ${ }^{c}$, Candidate of Phylological science Head of Translation Studies and Foreign Languages department Atyrau university, Address: Bimaganova Str. 7, Atyrau, Kazakhstan https://orcid.org/0000-0001-8863-948X

\section{Suggested Citation:}

Tolkyn, Z., Anar, A. \& Khatifovna, A. K. (2021). Organizational Technics for Developing the Leadership Potential of students in self-government. Cypriot Journal of Educational Science. 16(5), 2879-2886. https://doi.org/10.18844/cjes.v16i5.6381

Received from July 3,2021; revised from August 22,2021; accepted from October 28,2021.

${ }^{\circ} 2021$ Birlesik Dunya Yenilik Arastirma ve Yayincilik Merkezi. All rights reserved.

\begin{abstract}
Organizational technics for developing the leadership potential of students in self-government has been a topic of debate in recent times. The article aims to describe ways to allow students to develop creative initiatives in self-government, responsibility and professionalism, independence and social activity. Trends have been defined for improving pedagogical forms and methods of work with students. Develop leadership potential in student self-governance. Improvement of research, cultural, educational, athletic, information and communication skills within student union, which allows young people to develop their professional competencies. Leadership skills require active and professional self-management and self-improvement. A communication culture develops as a result of student autonomy and the manifestation of leadership potential. The authors argue that students, as active participants in the university's public life, develop their leadership potential by participating in the formation of traditions. Quality preparation of students for a future professional career is possible only if the leadership potential of professional responsibility is developed.
\end{abstract}

Keywords: communication culture; free will; leadership potential; self-government; self-improvement; organisational technics

\footnotetext{
* ADDRESS FOR CORRESPONDENCE: Zhumasheva Tolkyn, PhD student, Department of pre-school education and social pedagogy, Abai Kazakh National Pedagogical University, Dostyk ave.13, 050010, Almaty, Kazakhstan E-mail address: $\underline{\text { d.s.tolkyn@mail.ru }}$
} 
Tolkyn, Z., Anar, A. \& Khatifovna, A. K. (2021). Organizational Technics for Developing the Leadership Potential of students in selfgovernment. Cypriot Journal of Educational Science. 16(5), 2879-2886. https://doi.org/10.18844/cjes.v16i5.6381

\section{Introduction}

Student self-government is a student public organization that protects the interests of students, defends their rights, participates in the development of programs aimed at solving problems, conducts research, promotes student leadership.Student government: Research of effective methods of educational work; Learning the fundamentals of socialization; Mastering the tasks of research, formulation and generalization, research work. Self-government includes 4 action areas: cultural and cognitive, research, practical, social and legal self-protection (Drygina, 2003).

Leadership is an integrated quality that ensures effective collaboration using personal and business resources. Leadership potential is determined by needs, motives, responsibilities, worldview (Meneghetti, 2004). Assessing leadership capacity requires team accountability, positive attitudes towards people, knowledge, inspiration and learning, the ability to defend one's views, the ability to make wrong decisions.

The purpose of creating conditions for student self-government is to develop leadership potential. The development of leadership potential within self-government contributes to the formation of a creative, proactive, intelligent, self-developing, highly humane, democratic consciousness, a qualified professional. It is a big deal to create conditions to develop the potential of the future leader (Terziev, 2015). Due to this fact, the leadership potential of the youth contributes to the development of an independent personality, who is socially active in the student self-government environment. Leadership potential in the self-management and self-development field or the achievement of great results is impossible without willpower.

Will is the ability of a person to consciously and purposefully regulate and control his/her behaviour and actions, which is manifested in the ability to mobilize mental and physical capabilities to overcome difficulties and obstacles on the way to achieve goals. Will is conscious regulation of one's activity and behaviour, ensuring overcoming difficulties in achieving the goal. (Kelly, 2012). Willpower and decision making are interconnected (Baumeister \& Tierney, 2012). university Tasks to achieve the development of the leadership potential of youth in student self-government are the following: humanistic and tolerant approach; help to enrich the experience of communicating with yourself, with the society and the world around you; strengthening the role of organizations, clubs in the professional development of students; creating a socio-cultural space for the implementation of socially significant initiatives, expanding the worldview; Increasing the effectiveness and success of education and creative activity; Increasing the availability of relevant information for future professions through scientific creativity; Development and support of student initiatives; Strengthening the democratic ways of life, high mutual demands and a sense of social justice; a healthy psychological atmosphere, moral foundations of future professionals; team building contribution, consolidation and resistance to frustration; development of moral principles and responsibilities in teamwork; strengthening the role of students' clubs to develop students' formation of worldview (Singer-Brodowski \& Bever, 2016).

It is crucial to constantly update teaching methods, developing students' ability to be competitive, responsible, adaptable to changing circumstances, intellectual and creative self-government in the context of the current socio-political and economic crisis. University students are energetic, creative, independent, courageous, active, creative young people capable of motivating and influencing each other. Specific qualities of students, such as "creativity", "motivation", "independence", "action", "courage", which are observed in self-government, often coincide with the concept of "leadership potential". 
Tolkyn, Z., Anar, A. \& Khatifovna, A. K. (2021). Organizational Technics for Developing the Leadership Potential of students in selfgovernment. Cypriot Journal of Educational Science. 16(5), 2879-2886. https://doi.org/10.18844/cjes.v16i5.6381

Today, leadership potential has different historical and social dimensions. The issue of leadership capacity is rooted in the history of human relations. In public and political life, leadership potential is a trend that manifests itself in an authoritative individual. Leadership potential as a social phenomenon reflects the ethical and moral values of society and the individual.

Types of scientific potential for developing the leadership potential of young people in student self-governance: Personal potential is a system of individual qualities: a synthesis of personal and professional skills that forms the basis of professional and personal development and provides an appropriate level of professional training and success in subsequent activities. Its structure includes epistemological potential - the stage of general education, professional and specific training of a student (Baumeister \& Tierney, 2012).

The axiological potential is a system of professional goals, values, life principles and moral principles. The positive potential is the ability to effectively organize its future professional activity. Communication potential - communication, understanding, communicative qualities, skills and abilities. Creativity is the ability to create and discover new, unique and non-standard actions. The intellectual potential is a complex description of the level of development of reason, intelligence, thinking, logical abilities. The intellectual potential is determined by the level of development of the education and enlightenment system, science, culture, genetic resources of society:

1. Leadership potential is the ability to lead, follow and guide not only yourself but also others, to achieve a given goal. If the leader has the overwhelming majority of the above-mentioned capacity to perform such complex tasks, the university can be considered to have fulfilled its mission to train future professionals, because developing the leadership potential of students at the university creates the professional competencies necessary for a future career.

2. Intellectual and creative competencies are reflected in professional tasks preparation, ability to justify the abandonment of standard solutions, ability to assess the situation from a practical point of view, ability to use reasoned and purposeful information.

3. Business Competencies: Readiness for long-term performance of high-performance work, ability to solve non-standard and adequate evaluations of results, ability to respond rationally to information, ability to target algorithms, to act diligently. To achieve the objectives, to present ideas and to concretize them, to describe the ability to determine the means of implementation.

4. Socio-communicative competencies characterize the ability to self-organization, the ability to resolve conflicts when solving team problems, communication, the ability to feel and understand the emotions of others, the ability to observe the invisible features of phenomena.

\section{Methods and Materials}

This study is a short paper on organizational technics for developing the leadership potential of students in self-government. The research describes the current state on the field of interest.

\section{Findings}

Effectively develop the leadership potential of students as a result of the activities of selfgovernment on organizational technics $s$ at the university. Organizational technics often arise when the achievement of joint goals is possible through a combination of different purposes, or when the accomplishment of individual goals is possible through achieving joint goals. A distinctive feature of the organizational technique is purposefulness. Organizational technics act as the target community. Achieving this collective goal requires the introduction of hierarchy and governance. Organizational 
Tolkyn, Z., Anar, A. \& Khatifovna, A. K. (2021). Organizational Technics for Developing the Leadership Potential of students in selfgovernment. Cypriot Journal of Educational Science. 16(5), 2879-2886. https://doi.org/10.18844/cjes.v16i5.6381

technics emerged as a tool for solving social problems and achieving goals. From this point of view, organizational goals and functions, the effectiveness of results, character motivation and motivation, etc. come first.

The club is established as a student association, a real social environment. From this position, the club is in the form of a set of social groups, statuses, norms, leadership relationships, associations, conflicts. At the university, the club is considered as a personal structure of relationships and norms determined by cultural factors.

The main issues in the club are balance, self-government, division of labour, leadership, leadership. All these qualities are relatively independent, there are no clear boundaries between them, and the technological aspect can divide them into stages, operations, procedures. Student selfgovernment actively develops when organizing the work of clubs. The development of the leadership potential of students in self-government activities in the club can be effectively carried out through organizational technology. A student club is a place where all creative students of the university aspire. By participating in the activities of student clubs, the student has the opportunity to spend their free time interestingly, participating in their interests.

Organizational technics:

- students have the opportunity to express creatively;

- develop logical, critical thinking, research and creative skills;

- develop a professional style of speech and oratory;

- develop a professional style of speech and oratory;

- Increases the capacity to independently search, process and receive information;

- develop communication skills and teamwork;

- increase tolerance and confidence

Student autonomy will increase. Extra-curricular activities have been developed and implemented and consultants will be assigned. Trends; event, language learning, readership, scientific, art technology, music, cinema and theatre, sport, debate, tourism, volunteers and social media marketing (Soykurt and Uzunboylu, 2018).

Event - The work of the event manager is varied. They are focal points that bring together students from other fields to organize planned events.

Language Learning - Students gather students who are interested in learning a language, determine which language they want to learn, and divide them into groups. Organize speaking clubs.

Readership - readers allow students to read the works of different authors, as well as guide and motivate young people to read interesting books of different genres (classical or modern). They gather at the appointed time, analyze the work and exchange views on life.

Scientific - students interested in scientific research are selected for the Department of Scientific Knowledge. They ask other students to write research projects, articles, reviews, abstracts and essays on topical issues related to society. At the appointed time, students meet, exchange views and assess the level of the assignment. 
Tolkyn, Z., Anar, A. \& Khatifovna, A. K. (2021). Organizational Technics for Developing the Leadership Potential of students in selfgovernment. Cypriot Journal of Educational Science. 16(5), 2879-2886. https://doi.org/10.18844/cjes.v16i5.6381

Art technology unites all those who are interested in creating works from different materials, who choose a theme according to the plan.

Musical - consists of students who are fond of singing, dancing and music. They are responsible for the music department of scheduled events. New talents will be revealed. There is an opportunity to participate in competitions.

Cinema and theatre - Cinema and theatre department is closely connected with cultural centres. Plan performances in theatres in advance and organize ticketing. Select movies or dramas to encourage students to come together and watch and then share their opinions orally or in writing.

Sport - consists of sports-oriented students. Organize competitions and sports contests among students. Promotes interest and participation of students in sports. Promote a healthy lifestyle.

Debate - Teaches the principles of Debate: students treat each other and others with respect and tolerance; to be honest; focuses on adhering to the undefeated principle. It is important to hold a debate among students at the university. Debate is a way for students to improve their skills in debating and proving their point of view at a meeting in any future professional activity.

Tourism - organizes student travel, introduces tourists to the places of interest that attract tourists from around the world, motivates them to travel to other countries, organizes group trips for students. Young people have more respect for their country and their land. Organize actions related to the protection of the environment, the preservation of the country and the land in general, the values of nature.

Volunteers are students who serve willingly without being forced or paid. Recognize himself as a special person of human activity, aimed at selfless, voluntary assistance, unwavering support to people in need and difficult situations. He/she understands that he/she is a person who works for free and voluntarily in the interests of society. It should be noted that the vast majority of students are motivated to join the ranks of volunteers.

Social media marketing SMM is a very important field. In the current pandemic, the situation is difficult to imagine in a society without marketing. Twenty years ago, there was no information about the SMM specialist or the specialities that make mobile applications. Now it is impossible to predict what will happen in the next ten years and what will be achieved in society. During the last years, IT is becoming more attractive and more popular. Nowadays, social platforms have become full-fledged marketing. SMM is not possible for trade, education, education, information retrieval and attraction. The 21st century depends on adherence to the SMM strategy.

The organization of work in these areas promotes respect for future professions among students, encouragement of innovative activities, increasing the mobility of professionals by market requirements and the development of professional leadership potential.

Self-government organization: - organizes the active participation of students in the implementation of leadership tasks and equal distribution of services. Self-organization checks the work progress; promotes a comprehensive analysis of issues; assists in the organization, conduct, summarizing of social work; organizes the selection of the best research work and distributes them among universities, cities, etc. competitions; nominates candidates for business trips to other universities to exchange experience deals with the issues of awarding the winners, maintaining social systems at a professional level; Exchanges research and cultural work with students of other universities. 
Tolkyn, Z., Anar, A. \& Khatifovna, A. K. (2021). Organizational Technics for Developing the Leadership Potential of students in selfgovernment. Cypriot Journal of Educational Science. 16(5), 2879-2886. https://doi.org/10.18844/cjes.v16i5.6381

At the same time, when a student becomes a member of a group, the emphasis is on tolerance for other people's opinions and ideas, and mutual respect and understanding. In carrying out the tasks, the student works in a team environment and works as a member of a team. Methods of creating effective team relationships between students. The ability to communicate is the most convenient aspect of group work, but it requires not only the ability to speak, but also the ability to listen, so there are a few basic rules that students need to know:

- take turns when speaking;

- active listening;

- ask a question;

- propose;

- share their thoughts and opinions and respect the ideas and opinions of others;

- discussion of proposals, ideas and opinions with the team;

- help and request for help; - comment and request for clarification;

- comment and evaluate them;

- group decision-making and consensus;

- summarizing the discussion;

- to present consistent evidence.

The main task of teachers for the effective functioning of student self-government organizations at the university is to organize and support their independent activities in the role of consultants, colleagues, experts. The university is a personal and professional social environment for students. Leadership potential is a social phenomenon observed in a specially organized group that pursues a common goal. Therefore, the development of leadership potential of young people in the field of student self-government is formed by the graduates with a bachelor's degree:

- the ability to develop the ability to influence the individual and the group, to work in a team and to attract, guide, persuade, inspire, inspire to a useful result for all, its effectiveness;

- business, diligence and effective communication, purposefulness, personal strength, competence and psychological stability;

- subjectivity, independence, critical thinking, personal activity, reflexivity and initiative, etc.

According to my mind, leadership potential is a phenomenon in which a person influences a social (opinion, evaluation, communication) and the behaviour of a group or its members, while leadership style is a personal, subjective leadership of the leader through organizational behaviour and communication. - is a constant set of psychological characteristics. The development of leadership potential of students within self-government can be explained in two ways:

- First of all, leadership potential is high professionalism. A leader is a subject of independent actions. The learning technology depends on the content, forms of knowledge and strategy.

Second, leadership capacity is a position of self-governance, where the leader is the representative of the education, which depends on the education system and its structure, functions and quality.

Professional leadership opportunities are developed through student self-government: 
Tolkyn, Z., Anar, A. \& Khatifovna, A. K. (2021). Organizational Technics for Developing the Leadership Potential of students in selfgovernment. Cypriot Journal of Educational Science. 16(5), 2879-2886. https://doi.org/10.18844/cjes.v16i5.6381

- Critical Thinking - The ability to receive, search and absorb information.

- Reasons for the consequences of errors. Creativity - not to lose confidence in various situations, adaptation, the ability to make non-standard decisions, the ability to assess the situation from different ways, to support and develop the creative abilities of others.

- Communication- the ability to build a positive relationship, to create a positive atmosphere, to resolve, avoid and prevent conflicts, to negotiate effectively.

- Coordinator - contributes to the formation of professional competencies, such as finding ways to optimize teamwork.

Also, among the students there are experienced organizers (high level of leadership potential development); potential organizers (medium level) and beginners (low level) are identified.

\section{Conclusion.}

Self-government has a positive effect on the development of leadership potential. Student self-government made it possible to determine the methods and forms of leadership development. Leadership development work helps students focus on leadership, identify leadership qualities, motivate, stimulate, create favourable conditions for the development of leadership qualities. The methodological complex of clubs, organizations are aimed at identifying effective forms, technologies, methods of organizing the classroom and extracurricular activities by explaining the theory and practice of leadership.

Students understand the effectiveness of building positive relationships in self-government. Leadership potential is characterized by a clear direction of influence on team members and a pattern of behaviour. Forms, tools and methods of practical implementation are very important for the development of leadership potential of young people in student self-government. The informative characteristics of the set of qualities that make up the leadership potential of students through selfmanagement are revealed: personal qualities, organizational-business, status qualities.

\section{References:}

Baumeister, R. F., \& Tierney, J. M. (2012). Willpower: Rediscovering the greatest human strength. Penguin. https://www.amazon.com/Willpower-Rediscovering-Greatest-Human-Strength/dp/0143122231

Drygina, I. V. (2003). Activation of leadership potential of the personality in the educational process at the university. pp.22

Kelly, McGonigal. (2012). The Willpower Instinct.Self-Control Works, Why It Matters, What You Can Do to Get More of It. pp.312. https://www.amazon.com/Willpower-Instinct-Self-Control-WorksMatters/dp/1583335080

Meneghetti, A. (2004). Leadership Psychology. (2004) 256 pp.

Singer-Brodowski, M., \& Bever, H. (2016). At the bottom lines-student initiatives for sustainable development in higher education. Human ecology studies and higher education for sustainable development: European experiences and examples. Munich: oekm verlag. Barrineau, S., \& Anderson, A. (2018). Learning "Betwixt and Between": Opportunities and. https://www.oekom.de/ files media/titel/leseproben/9783865812995.pdf 
Tolkyn, Z., Anar, A. \& Khatifovna, A. K. (2021). Organizational Technics for Developing the Leadership Potential of students in selfgovernment. Cypriot Journal of Educational Science. 16(5), 2879-2886. https://doi.org/10.18844/cjes.v16i5.6381

Soykurt, M., Uzunboylu, H. (2018). The impact of creative activities integrated into curriculum for tolerance education and teachers' reflections. Quality and Quantity, 52, 913-927, https://doi.org/10.1007/s11135-017-0543-2

Terziev, V. (2015). Opportunities for improving the efficiency of the social adaptation of servicemen discharged from military service in Bulgaria. Opportunities for improving the efficiency of the social adaptation of servicemen discharged from military service in Bulgaria: monograph/V. Terziev.-Novosibirsk: Publisher CRNS. https://papers.ssrn.com/sol3/papers.cfm?abstract id=3010985 